\title{
CLASTIC HUNTITE IN UPPER NEOGENE FORMATIONS OF THE KOZANI BASIN, MACEDONIA, NORTHERN GREECE
}

\author{
JOSÉ P. CALVO', MICHAEL G. STAMATAKIS ${ }^{2}$, AND ANDREAS C. MAGGANAS ${ }^{2}$ \\ I Departamento de Petrologia y Geoquimica, Facultad de Geologia, Universidad Complutense, 28040 Madrid, Spain \\ 2 Department of Geology. University of Athens. Panemistimiopolis Ano Ilissia. 15784. Athens, Greece
}

\begin{abstract}
An unusual carbonate mineral, huntite $\left(\mathrm{Mg}_{3} \mathrm{Ca}\left(\mathrm{CO}_{3}\right)_{4}\right)$, is present in Upper Neogene lacustrine formations of the Kozani Basin, Northern Greece. This carbonate, either pure or mixed with variable proportions of hydromagnesite and magnesite, forms extensive deposits that accumulated in ponds on a lake-margin carbonate flat. Although labile and metastable, huntite also is the main detrital component of fluvial-dominated delta sequences in some parts of the basin. Clastic huntite is present mainly in foresets, trough cross-stratified units, and channel forms in terrigenous lithofacies towards the basal part of deltaic assemblages. Detachment of fragments from cohesive huntite pond deposits may have been favored by expansion through wetting rather than by desiccation and further contraction of the chemical sediment. This first documented occurrence of clastic huntite places some uncertainties on the presumed chemical and mechanical instability of huntite under natural conditions.
\end{abstract}

\section{INTRODUCTION}

Huntite, first described by Faust (1953), is a relatively rare $\mathrm{Mg}$-rich carbonate mineral $\left(\mathrm{Mg}_{3} \mathrm{Ca}\left(\mathrm{CO}_{3}\right)_{4}\right)$. Huntite deposits have been recognized in various settings. including weathered volcanic tuffs and dolomitic formations (Faust 1953; Faust and Callaghan 1958; Cole and Lancucki 1975; Skinner 1958; Vitaliano and Beck 1963; Shayan 1984), karstic environments (Baron et al. 1957; Thrailkill 1965), coastal sabkhas (Kinsman 1967; Perthuisot 1971; Perthuisot et al. 1990), and continental lacustrine environments (lrion and Müller 1968; Müller et al. 1972; Stamatakis et al. 1989; Zachmann 1989). More recently, Renaut (1993) reported huntite in highly alkaline carbonate playas of the Cariboo Plateau, Canada.

The conditions of huntite formation have not been clearly deciphered, and various mechanisms for huntite precipitation have been proposed: precipitation from percolating waters traversing dolomite, magnesite, and/or hydromagnesite deposits (Faust 1953; Baronet al. 1957; Skinner 1958; Vitaliano and Beck 1963; Thrailkill 1965; Zachmann 1989), early diagenesis from magnesium-rich pore solutions under strong evaporitic conditions (Kinsman 1967), or bacterial reduction of sulfate during the initial stages of sabkha formation (Perthuisot et al. 1990). In lakes, huntite is precipitated only at $\mathrm{Mg} / \mathrm{Ca}$ ratios much higher than required for dolomitization (Irion and Müller 1968: Müller et al. 1972), huntite being envisaged as a secondary carbonate product from precursor aragonite and/or hydromagnesite (Muiller and Förstner 1975), but no data about the time required for this transformation was given. Whatever the exact mechanism of formation, huntite is considered to be metastable in earth-surface conditions (Faust 1953: Wolberg et al. 1989; Perthuisot 1990).

The Neogene Kozani Basin in Macedonia, northern Greece, contains extensive huntite in continental lacustrine deposits, in spite of its supposedly metastable character. Here, huntite is associated with other $\mathrm{Mg}$-rich carbonates, mainly hydromagnesite and magnesite (Wedzenstein 1975; Stamatakis et al. 1989: Zachmann 1989). One of the most striking features of these deposits is that huntite is present locally as a clastic component of terrigenous deposits. Given that primary huntite seems to have a low preservation potential and that the physical properties of huntite do not favor its behavior as a clastic material, its occurrence is somewhat problematic.

Here we provide a description of this clastic huntite, and a sedimentological interpretation of the deposits containing clastic huntite. Some ob- servations are made in order to explain the probable mechanism of detachment and reworking of huntite particles from cohesive carbonate deposits.

\section{HUNTITE IN THE KOZANI BASIN}

The Kozani Basin is in the northernmost part of Greece (Macedonia region) (Fig. 1), in the so-called Pelagonian Zone (Mercier 1973). It was formed by post-Alpine extensional movement that resulted in development of several tectonic depressions (Kozani, Florina, Ptolemais, Elassona) along a NNW-SSE trend (Dermitzakis and Papanicolau 1981). In the Kozani Basin, margins are bounded by NW-SE and NE-SW normal faults that are locally associated with small strike-slip faults. The basin, $400 \mathrm{~km}^{2}$ in area, is surrounded by Mesozoic limestone and dolostone and ophiolitic ultrabasic rocks.

In the Kozani Basin, Mg-carbonate deposits are present in the upper part of a 400-500 m thick sedimentary succession, ranging from Upper Miocene to Pliocene (Anastopoulos et al. 1980; van de Weerd 1983; Velitzelos and Knobloch 1986). This succession has been divided into two units, the Lower Neogene Series mainly fresh-water limestone and marlstone with intercalated lignite seams, and the Upper Nengene Series, which comprises dolomitic marlstone, limestone and sandstone (Anastopoulos and Brousoulis 1973). The latter unit is up to $100 \mathrm{~m}$ thick and contains distinct white $\mathrm{Mg}$ rich carbonate layers and/or lenses. Huntite, hydromagnesite, and minor magnesite are the common components of these carbonate deposits (Stamatakis et al. 1989; Zachmann 1989). Comparison of the two units suggests a shift toward a warmer and drier climate, which resulted in accumulation of evaporitic carbonate deposits in the upper part of the Tertiary lacustrine successions (Stamatakis et al. 1989).

Major Mg-rich carbonate accumulation appears to be spatially related to Triassic dolostone and limestone that either extends along the basin margin or forms irregular, tectonically uplifted areas in inner parts of the basin (Fig. 1). In the western part of the basin, Mg-rich carbonate deposits are near ophiolitic rocks. From the proximity of $\mathrm{Mg}$-carbonate deposits to faultbounded basement rocks and the common presence of aragonitic travertine (sinter) adjacent to Mg-carbonates, we postulate a mechanism for the formation of these carbonates through the feeding of solutions rich in $\mathrm{Mg}^{+2}$ and $\mathrm{HCO}_{3}{ }^{-}$into springs, which is basically in agreement with that proposed by Zachmann (1989). Concentration of waters rich in magnesium and carbonate under evaporative conditions in ponds would account for the formation of hydromagnesite and huntite. In this model, magnesite is considered to be a later diagenetic product after these $\mathrm{Mg}$-carbonate minerals.

Huntite is the predominant $\mathrm{Mg}$-carbonate phase in some parts of the basin (Neraida, Stena Portas, Vathylakhos, Yiari-Kayiá, Eaní; Fig. 1). Carbonate mineralogy was determined by XRD analysis of more than 200 samples from the aforementioned deposits, as well as from other scarce occurrences in the basin. Huntite identified by XRD then was imaged by SEM (equipped with EDAX). Some selected samples were analyzed in parallel (at the National University of Athens, US Geological Survey in Reston, Virginia, and Universidad Autónoma de Madrid) to confirm their identification as huntite. In most cases huntite is accompanied by varying proportions of hydromagnesite and/or magnesite, although as in Neraida (32 samples), huntite is almost pure.

Huntite deposits in the basin are internally massive, commonly with a nodular structure. These deposits vary from pocket-like and rounded lenses, up to $2 \mathrm{~m}$ thick and 3-5 $\mathrm{m}$ wide, within green sandy claystones, to layered 


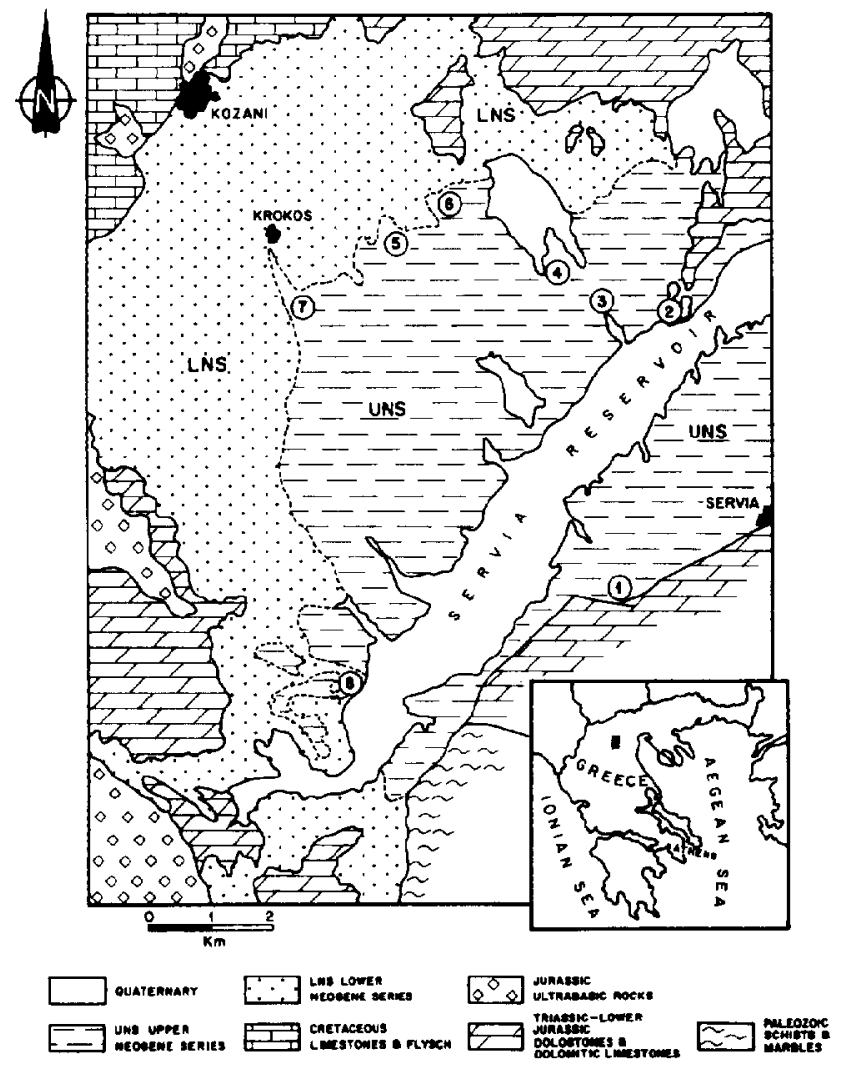

MUMTITE oEPOSITS (1) STEMA PORTAS (2) NERAIOA (3) VARI-KAYIA

(4) vathylakos (3) potistaa (6) agrotis (1)krokos (9) Eani

FIG. 1.-Schematic geologic map of the Kozani Basin with location of clastic and massive huntite deposits: 1, Stena Portas; 2, Neraida; 3, Yiari-Kayiá; 4, Vathylakhos; 5. Potistra; 6, Agrotis; 7, Krokos; 8, Eaní.

deposits of large lateral extent interbedded with claystone and dolomitic marl. The largest huntite deposits are in Neraida, where the thickness of the Mg-carbonate exceeds $8 \mathrm{~m}$ and can be followed laterally for several hundred meters. Here, huntite overlies bedded sandy claystone and in turn is capped by dome-like travertine. In close view, huntite deposits are pure white with a powdery appearance. When wet, it is highly plastic and breaks into mushroom-like surfaces. Huntite consists of a massive aggregate of huntite crystallites $(1-2 \mu \mathrm{m})$ with scattered, larger $(5-10 \mu \mathrm{m})$ subhedral crystals (huntite?) and quartz grains. Under SEM, huntite consists of rectangular to square platelets, $1-2 \mu \mathrm{m}$ in size, forming face-to-face aggregates (Fig. 2). The rock is quite porous as a result of edge-to-face relationships among distinct aggregates. These characteristics differ from those of huntite from Sabkha El Melah, Tunisia (Perthuisot et al. 1990), where huntite is present as elongated aggregates of minute $(0.5 \mu \mathrm{m})$ crystals of bacterial origin.

In addition to the massive occurrences, huntite is the main component of carbonate clasts in terrigenous facies associated with Mg-carbonate deposits in several parts of the basin.

\section{CLASTIC HUNTITE DEPOSITS}

Clastic deposits containing fragments of huntite have been found at several places in the basin. The best exposed sections are at Stena Portas, Potistra and Agrotis, and near the village of Krokos (Fig. 1). The Stena Portas outcrops allow assessment of the geometric relationships between

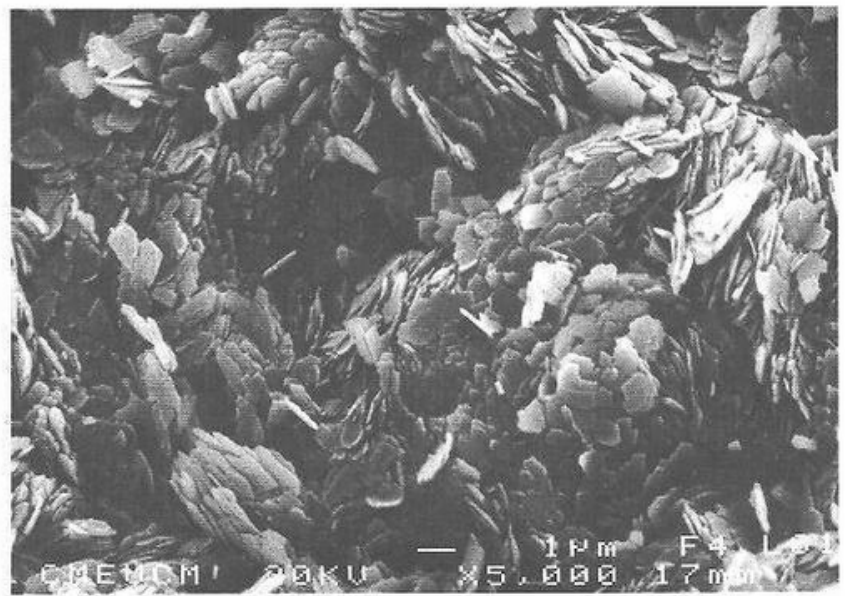

FIG. 2.-SEM photomicrograph of huntite from clastic deposits of Agrotis. Note the complex arrangement of platy huntite crystals resulting in face-to-face aggregates with a flocculate appearance.

chemically precipitated huntite and hydromagnesite deposits and terrigenous facies containing reworked huntite. In other places, with the exception of a small outcrop near Krokos, clastic huntite has been found in isolated outcrops, and its interpretation has so far been restricted to the sedimentary features shown by beds that contain huntite fragments. In all cases, the carbonate clasts were identified as huntite by XRD. The texture of huntite forming the clasts is the same as in the massive deposits (Fig. 2).

\section{Stena Portas Section}

Description.-The section in Stena Portas is a succession of chemical and clastic marginal lacustrine facies up to $100 \mathrm{~m}$ thick. Huntite is present in two distinct horizons showing a similar sequential arrangement (Fig. 3A). Sequences containing huntite comprise, from bottom to top, laminated carbonate with poorly developed fenestral (algal?) vugs and fine root bioturbation and marlstone, massive huntite-hydromagnesite beds with minor proportions of magnesite, and clastic, mainly sandy beds that host abundant huntite fragments up to a few centimeters in size. These clastic facies, which cut into the massive Mg-carbonate deposit, consist of both crudely laminated clayey sands showing small-scale ripples and local scouring and interbedded well-defined, small (up to a few decimeters thick), slightly erosive, sand-filled channels. Clasts of huntite, mixed with variable proportions of mud chips, are commonly scattered or arranged in thin strata within the clayey sand beds (Fig. 4). Well-sorted, finer-grained huntite clasts are also found in sand-filled channels.

Interpretation.-The basal carbonate, mainly dolomicrite, and marl deposits precipitated in relatively dilute waters in a shallow lake-margin environment close to the southern border of the basin (Fig. 1). Further accumulation of huntite took place in restricted water bodies, i.e., ponds, subjected to stronger evaporation (Müller et al. 1972). This interpretation is based on the discontinuous geometries of the Mg-carbonate deposits. After filling of the ponds, the huntite deposit was reworked by channelized streams, leading to entrainment and further mixing of huntite clasts with siliciclastic sand grains. The poorly structured nature of the clayey sand facies at the base of the thickening- and coarsening-upward sequence that overlies the huntite pond deposits indicates rapid deposition, probably related to hyperconcentrated flood flow. This facies was episodically eroded by dilute flows as recorded by small-scale sand-filled channels. Larger-scale sand-filled channels towards the top of the sequence reflect more normal stream flow and are interpreted as subaqueous distributary channels at the mouth of a river-dominated delta. The sharp top of the uppermost sandstone 
A

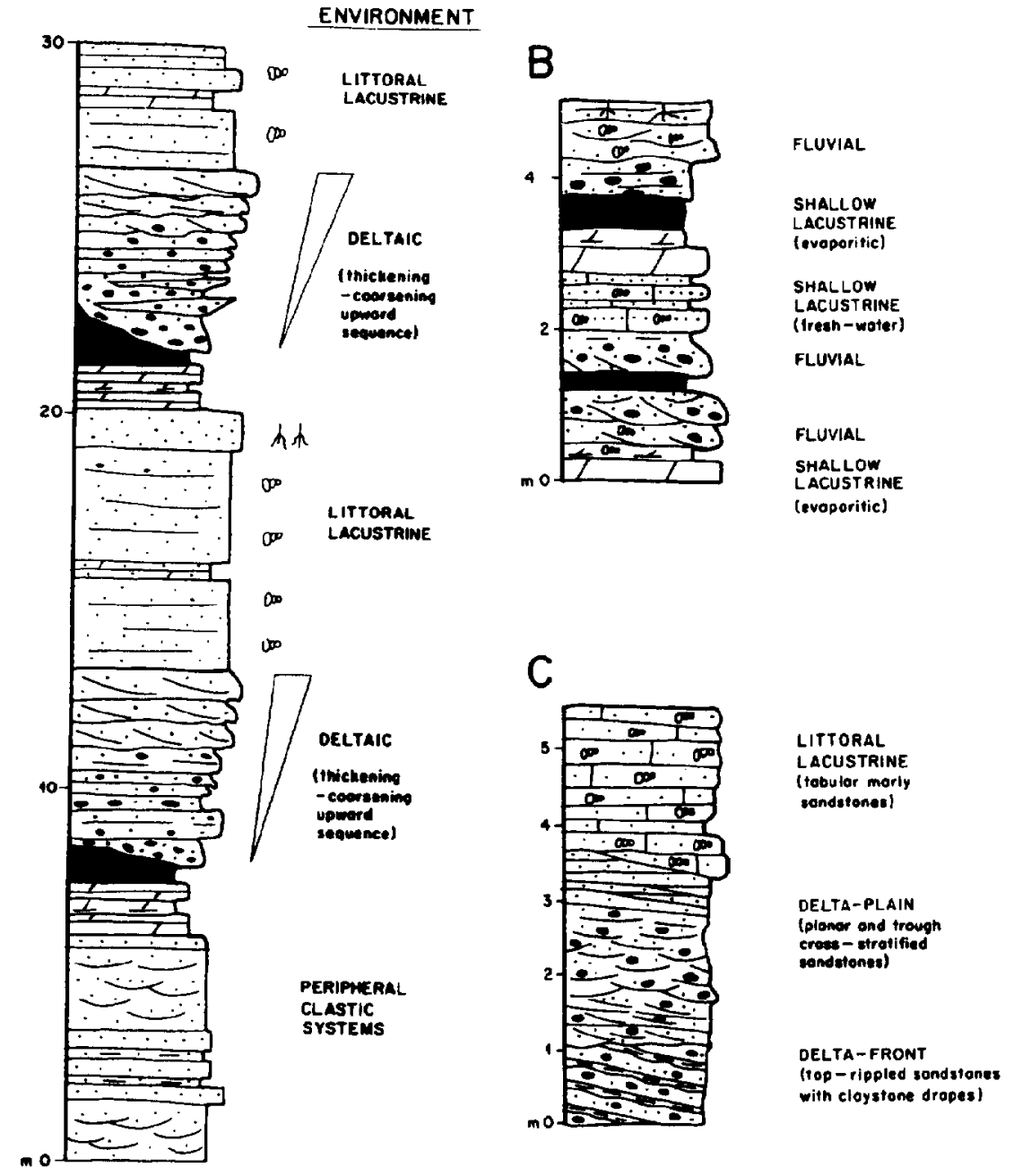

\begin{tabular}{|c|c|c|c|c|c|}
\hline & SAMDSTONE & 2 & DOLOSTOME & $\because \cdots$ & SANOY MARLSTONE \\
\hline$=$ & CLAYSTONE & & $\begin{array}{l}\text { MASSIVE } \\
\text { HUMTITE }\end{array}$ & 느 & DOLOMITIC MARL \\
\hline- & $\begin{array}{l}\text { QAnsTIC } \\
\text { HUNTITE }\end{array}$ & h & $\begin{array}{l}\text { ROOT } \\
\text { BIOTURBATION }\end{array}$ & & $\begin{array}{l}\text { TANGENTIAL } \\
\text { CROSS-STRATIFICATION }\end{array}$ \\
\hline$\infty$ & $\begin{array}{l}\text { SHELLS of } \\
\text { Lymoned o }\end{array}$ & & & ن & $\begin{array}{l}\text { TROUGH CROSS- } \\
\text { STRATIFICATION }\end{array}$ \\
\hline
\end{tabular}

Flg. 3.-A) Partial lithostratigraphic log of the Stena Portas section. Clastic huntite deposits are present in two different horizons associated with deltaic sequences that show typical thickeningand coarsening-upward trends. B) Lithostratigraphic $\log$ from a small section near the village of Krokos showing both massive and clastic huntite beds. C) Lithostratigraphic log and facies interpretation of the Agrotis section.

in the sequence may indicate rapid channel abandonment followed by further littoral lacustrine facies. The facies arrangement of the clastic-huntitebearing terrigenous deposits in Stena Portas is similar to that described by Farquharson (1982) and Glover and O'Beirne (1994) from Mesozoic and Carboniferous river-dominated lacustrine deltas, respectively.

\section{Krokos Section}

Description.-Near Krokos (Fig. 1), clastic huntite is present in two small outcrops showing an alternation of slightly erosive, crudely laminated to cross-stratified channel sandstone, marlstone, dolostone, and occasional, thick massive huntite-magnesite beds up to $15 \mathrm{~cm}$ thick (Fig. 3B). Wellrounded clasts of huntite, up to $3 \mathrm{~cm}$ in diameter, are found mainly in crudely laminated sandstone as well as at the bases of the small channels.
Shells of Lymnaea auriculata are abundant in both the sandstone and the marlstone.

Interpretation.-The Krokos sequence was formed in a marginal lake environment under the influence of streams entering the lake. In this setting, massive huntite deposits accumulated either as a final precipitation term from $\mathrm{Ca}-\mathrm{Mg}-\mathrm{HCO}_{3}$-saturated brines (dolostone-dolomitic marl-huntite sequences) or as pure huntite deposits between sand-filled channels. In both cases, the huntite represents periods of strong evaporation (Müller et al. 1972) and reduced clastic input in the shallow lake area. Further reactivation of the streams would both dilute the lake waters and rework the pond deposits. Slightly erosive bases and trough cross-lamination shown by the sandstone channels are indicative of transport by low-energy streams, which is corroborated by good preservation of gastropod shells. 


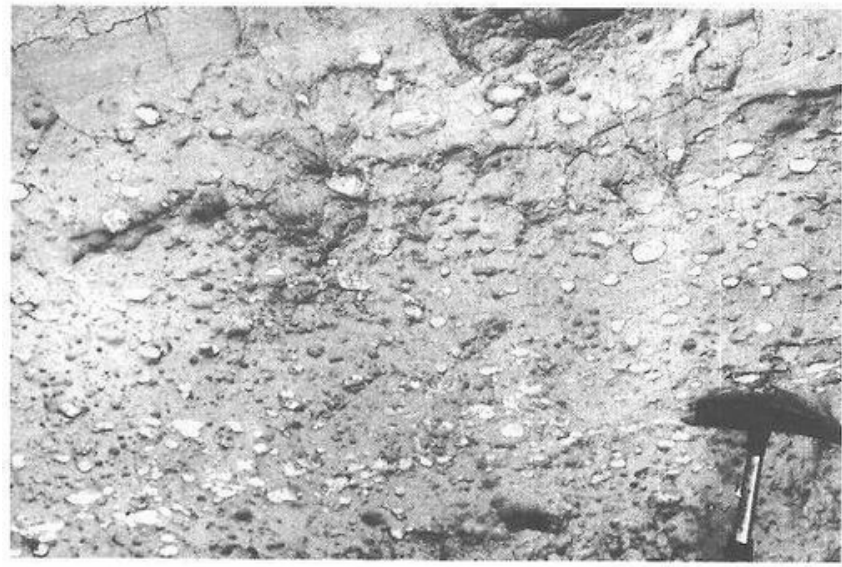

FIG, 4.-Clasts of huntite dispersed in crudely laminated, clayey sand, Stena Portas section. White clasts of huntite show variable grain size as well as different morphologies, from flattened to subspherical. Many huntite clasts are aligned with lamination of the sands (gently dipping from right to left). The hammer head is 19 $\mathrm{cm}$ long.

\section{Potistra and Agrotis Sections}

Description.-Clastic huntite in Potistra and Agrotis were studied in small openings for huntite prospecting. These are apparently aligned with the Krokos huntite described above (Fig. 1) and consist exclusively of huntite-bearing terrigenous deposits. In Potistra, the section comprises lowangle $\left(3-8^{\circ}\right)$ tangential-tabular foreset sands. Differences among laminae are outlined by changes in both packing and size of the huntite clasts (Fig. $5 A)$ as well as by local claystone drapes. Scour surfaces with gentle topography are apparent between the sets of laminae. Huntite clast sizes range from 0.2 to $2 \mathrm{~cm}$. Detailed observation reveals heterogeneity of the clast distribution within the laminae, which, in general, show pinch-out and/or grain fining across the single laminae. The matrix between huntite clasts is composed of silt- to sand-size grains of quartz, dolomite, and mica.

The section at Agrotis (Fig. 3C) records a sequence of basal foreset deposits overlain erosively by planar-laminated and small-scale trough cross-stratified sandstone (Fig. 5B). The component foresets, dipping at up to $15^{\circ}$, consist of $5-10 \mathrm{~cm}$ thick sandstone beds that are either amalgamated or separated by claystone drapes. These thin sandstone beds are ripple cross-laminated. The morphology of the current ripples is clearly observed at the top of the beds covered by claystone drapes. The upper part of the section is formed of crudely laminated calcareous sandstones with abundant shells of Lymnaea auriculata. Huntite clasts are common in both basal foreset and cross-stratified sands (Fig. 3C).

Interpretation.-Foreset beds containing huntite clasts in the Potistra section are interpreted as upper delta-front deposits. They represent parts of a deita where bed load fed by streams entering the lake accumulated rapidly at the discharge point. Gently inclined foresets are deposited by inertia-influenced currents. Scouring between the sets of laminae is indicative of small fluctuations in river discharge. All these features seem to be characteristic of Gilbert-type deltas (Ryder et al. 1976; Farquharson 1982).

The sequence in Agrotis is more complete than in Potistra and allows distinction between foreset delta-front deposits and topset cross-stratified sandstones that we interpret as deposited by delta-plain distributary channels. The presence of claystone drapes within the foresets is indicative of the episodic character of the discharge of streams entering the lake. Although partial, the section in Agrotis records the arrangement of foresets and topsets characteristic of Gilbert-type deltas. The thicknesses measured in these facies are of the same order as those reported by Farquharson
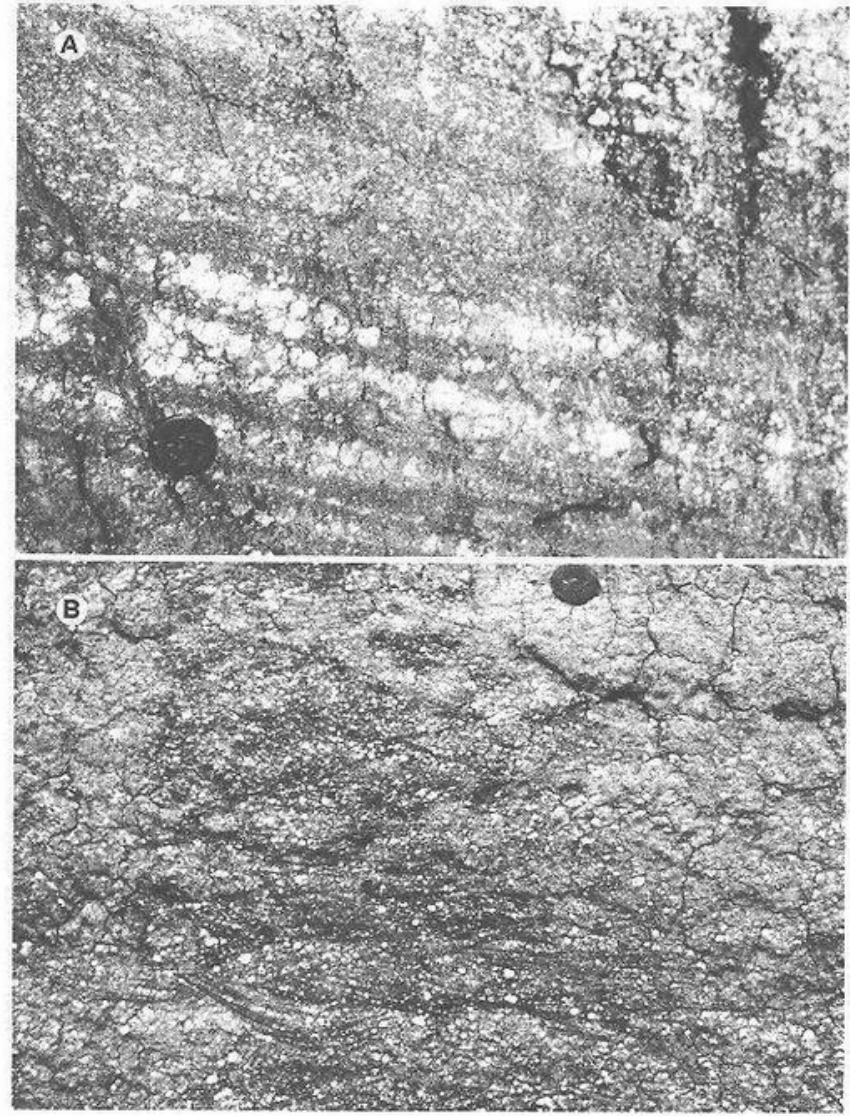

Fic. 5.-A) Foreset laminae consisting of fine to medium sands and clasts of huntite (in white), Potistra section. Coin diameter $=2.5 \mathrm{~cm}$. B) Small-scale trough cross-stratified sandstone with abundant clasts of huntite (white), Agrotis section. Coin diameter $=2.5 \mathrm{~cm}$.

(1982) from Mesozoic lacustrine deltas in Antarctica and are indicative of the shallowness of the lake in which the deltas formed.

\section{DISCUSSION}

The oldest occurrence of huntite has been documented by Wolberg et al. (1989), Bellis and Wolberg (1989) and Jameossanaie et al. (1990), who found it in continental, coal-bearing, Upper Cretaceous deposits of New Mexico. This occurrence suggests that huntite might be preserved in old sedimentary formations in spite of its metastable character. The presence of rather widespread huntite deposits in the Upper Neogene of Greek Macedonia (Wedzestein 1975; Stamatakis et al. 1989; Zachmann 1989) supports this assessment.

In the Kozani Basin, the formation of huntite and other Mg-carbonates was conditioned by supply of $\mathrm{Mg}$-rich waters from ophiolitic and dolomitic source rocks into a lake. The sedimentology of the huntite suggests that, whether associated with hydromagnesite and magnesite or as a pure $\mathrm{Mg}$ rich carbonate phase, it was initially deposited in ponds in marginal locations of the main lake system. This conclusion is in contrast with that proposed by Zachmann (1989), who suggested that hydromagnesite was the initial Mg-carbonate phase, precipitated under surface conditions in the lake environment, and magnesite was transformed from hydromagnesite during late diagenesis. Zachmann (1989) concluded that, finally, huntite formed after magnesite in the subsurface of the basin though at reduced pressures and low temperatures and as a result of the intermixing of $\mathrm{Ca}$ - 
rich karst waters with previous Mg-rich carbonate phases. namely magnesite. We will not discuss here the exact mechanism of huntite formation in the Kozani basin, but the presence of clastic huntite within terrigenous facies strongly suggests that the huntite is either a direct precipitate or an early diagenetic product from an other $\mathrm{Mg}$-rich carbonate precursor (probably hydromagnesite) formed in ponds, i.e., under surface conditions. In the latter case, the transformation from hydromagnesite to huntite might take place rapidly before reworking of the huntite by streams.

The scarcity of descriptions of the morphology and physical properties of huntite at the time of its deposition in modem sedimentary environments (Kinsman 1967; Perthuisot et al. 1990) presents a problem in determining a reliable mechanism of formation and further entrainment of the huntite clasts. The huntite probably started as a gelatinous mud, resembling the "yoghurt" appearance described for dolomite and other carbonates in recent evaporitic lakes (De Deckker and Last 1989; Warren 1989). The sediment then evolved into more indurated massive huntite. similar to that observed in present outcrops.

The petrography of huntite from outcrops in the Kozani Basin is envisaged as similar to that of the initial huntite, because the material maintains high and well-preserved microporosity (Fig. 2) which results in an extremely high absorbent capacity. No significant degradation, e.g., dissolution features or smoothing of crystal faces, is recognized in the huntite crystals. The behavior of the huntite deposits after wetting of outcrops provides a clue for understanding the mechanism of detachment of the huntite fragments: wetting of the huntite produces convex-up, "cauliflower"-like structures of varied diameter and iregular to wavy edges. Each single "cauliflower" structure is in turn cracked into smaller pieces whose edges extend downwards $2-3 \mathrm{~cm}$. In this way, formation of huntite clasts could be adequately expláined by breakage caused by expansion upon wetting rather than by contraction related to desiccation of the huntite deposits. This latter process, involving development of polygonal cracks, curls, or Hakes. is commonly invoked for the formation of intraclasts from cohesive carbonate beds (Shinn 1983; Allen 1982). but no evidence of such sedimentary structures or of related initial particle morphologies has been recognized in the huntite deposits.

Clastic huntite in the Kozani Basin is always associated with marginal fluvio-lacustrine facies that usually form part of deltaic assemblages. In Stena Portas, sandy terrigenous beds containing huntite clasts are located at the bases of thickening- and coarsening-upward units resembling, both in scale and facies arrangement, the mouth-bar type lacustrine deltas described by Farquharson (1982). These deltaic sequences, overlain by littoral lake facies, are indicative of the evolution of the lacustrine margin during a lake highstand. In the same way, clastic huntite in Potistra and Agrotis is associated with both medium-scale foreset sandstones and topset trough cross-stratified beds representing upper delta front and delta distributary channels, respectively. This sequence, typical of Gilbert-type deltas, is similar to that recognized by Ryder et al. (1976) in Lower Tertiary nonmarine deltaic assemblages from the Uinta Basin. The presence of gastropod-rich, littoral lacustrine facies filling the available accommodation space at the top of the deltaic sequence is, as in Stena Portas. indicative of a lake highstand.

With the foregoing as a basis, we propose a sedimentological model for clastic huntite deposits in the Kozani Basin (Fig. 6) that takes into account the initial formation of massive huntite in ponds on marginal carbonate Hats (in the sense of Ryder et al. 1976) during lake lowstands. Flooding of the marginal flats during later rises of lake level causes wetting and breaking of the huntite through expansion, facilitating entrainment of huntite clasts by streams and accumulation in lake-margin deltaic complexes.

Finally. preservation of clastic huntite requires some comments. The finding of huntite in the Upper Cretaceous (Bellis and Wolberg 1989) as well as in the Upper Neogene, as described here, undeniably indicates that this mineral has a much greater chance of long survival than previously betieved (Garrels et al 1960), even if the huntite is broken and dispersed

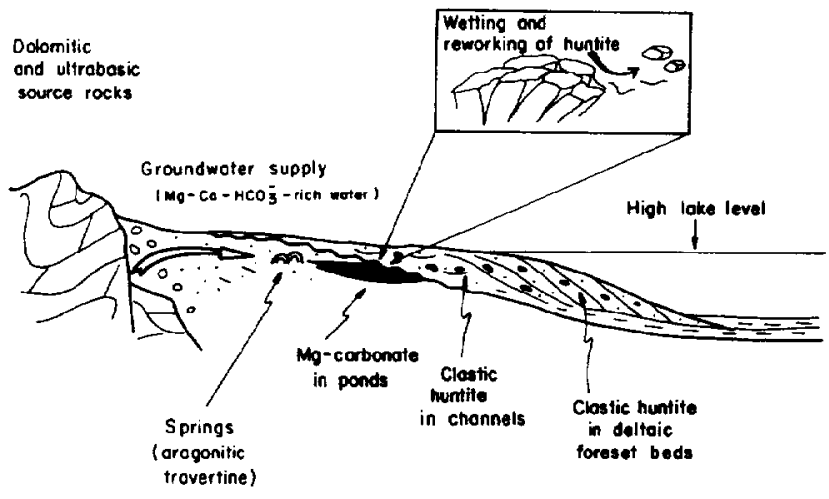

FlG. 6.-Idealized model for the formation of clastic huntite deposits in the Kozani Basin.

as fragments within a porous detrital sediment. The presence of clastic huntite in the Kozani Basin suggests that appropriate conditions for both rapid accumulation and preservation of the huntite clasts are attained in lake-highstand-related deltaic environments with moderate to high sedimentation rates. In this environment, $\mathrm{Mg}$-rich pore solutions in the terrigenous sediment would account for the higher preservation potential of huntite.

\section{CONCLUSIONS}

In spite of its labile and presumed metastable character, huntite is recognized to form a main detrital component in terrigenous beds of fluviolacustrine facies in the Kozani Basin. Huntite clasts accumulated after reworking of huntite pond deposits in nearby lake-margin carbonate flats. Most of the clastic huntite corresponds to delta-front facies and delta distributary channels in deltaic assemblages deposited during lake highstands. The physical response of huntite upon wetting suggests a process of formation of huntite clasts by wetting-induced expansion and further reworking by streams. Finally, the recognition of clastic huntite deposits strongly suggests that this mineral formed either as a direct precipitate or as a very early diagenetic product in ponds, which precludes a late diagenetic origin for the huntite in the Kozani Basin.

\section{ACKNOWLEDGMENTS}

This work was supported by the Ministries of Foreign Affairs of Greece and Spain through a joint research project developed in 1989-1991. We are thankful to Dr. Stelios Skounakis for his scientific and administrative assistance. We will never forget our friend and colleague, Emilio Elizaga, who started the work with us but died in September 1992. We acknowledge Dr. J.A. González Delgado for determination of gastropod faunas included in the studied sections. We are also indebted to Dr. Blair F. Jones (US Geological Survey, Reston) and Dr. Manuel Pozo (Universidad Autónoma, Madrid) for advice in contrasting $\mathrm{X}$-ray diffractograms of huntite in their respective laboratories. Dr. A.M. Alonso-Zarza is thanked for her careful reading and further comments to the manuscript. Thanks are also extended to Drs. Paul Wright, Ian J. Fairchild, and Bruce H. Wilkinson for their constructive reviews of the manuscript. We are also indebted to Paula Bayard, Julia Montesinos, and Agustín Blanco for their technical assistance.

\section{REFERENCES}

ALleN, J.R.L., 1982, Sedimentary Structures; Their Characteristics and Physical Basis, Volume l: Developments in Sedimentology, 30A, Amsterdam, Elsevier, $593 \mathrm{p}$.

Anastopollos, J., and Brolsouls, J., 1973, The Kozani-Servia lignite basin: Institute of Geology and Mineral Exploration, Athens, Mineral Deposits Research no. L, $77 \mathrm{p}$.

Anastopolos, J., Koukouzas, K., and Faugeres, L., 1980, Geological Map of Greece 1/50 000, Kozani Sheet: Institute of Geology and Mineral Exploration, Athens.

Baron, G., Cailuere, S., Lagrange, R., aid Pobegiln, T., 1957, Sur la présence de huntite dans 
une grote de l'Herault (La Clamouse): Académie des Sciences (Paris. Comptes Rendus. 6 245. p. $92-94$

BEIJIS, D., ANB Wol.trki, D.L., 1989, An unusual crcurrence of the mineral huntite from the Late Cretaceous, coal-bearing. Fruitland Formation. San Juan Basin. New Mexico (abstraci): Geological Society of America. Abstracts with Program. r. 21. p. 56.

Col., W.F., and LancuckI, C.J., 1975, Huntite from Deer Park. Victoria, Australia: The American Mineralogist, v. 60. p. $\mid 1301-113\}$

DE DeCKKFR, P., aNI LAST. W.M. 1989. Modern, non-marine dolomite in evaporitic playas of western Victoria, Australia: Sedimentary Geology, v. 64, p. 223-238.

Dermitzakis, M.. and Papanicilat, D.. 1981. Paleogeography and geodynamics of the Aegean region during the Neogene: Annales de Géologie des Pays Helléniques, v. 60, p. 245-288.

Farounarson, G.W., 1982, Lacustrine delias in a Mesozoic alluvial sequence from Camp Hill, Antarctica: Sedimentology, v. 29, p. 717-725.

Faust, G.T., 1953, Huntite, $\mathrm{Mg}_{3} \mathrm{Ca}\left(\mathrm{CO}_{3}\right)_{4}$, a new mineral: The American Mineralogist, v. 38 . p. $4-23$.

Faust. G.T. and Callaghan, E.. 1958, Mineralogy and petrology of the Currant Creek magnesite deposits and associated rocks of Nevada: Geological Society of America Bulletin, v. 69. p. 353-354.

Garrels, R.M. Thompsox, ME, anid Sifver. R. 1960. Stability of some carbonates at $25^{\circ} \mathrm{C}$ and one atmosphere total pressure: American Journal of Science, v. 258, p. 402-418.

G.over, B.W.. AND O'BEirne, A.M., 1994, Anatomy, hydrodynamics and depositional setting of a Westphalian $C$ lacustrine delta complex. West Midlands. England: Sedimentology, v. 4I, p. | 15-I 32 .

IrIox, G., AND MU.ler, G., 1968. Huntite, dolomite, magnesite and polyhalite of recent age from Tuz Gölü, Turkey: Nature, v. 220, p. 1309-1310.

Jameossanalt, A., Wolberg, D.L., and Beilus, D., 1990, Late Cretaceous (Campanian-Maastrichtian) palynology of a continuous Pictured Cliffs-Fruitland core. south-central San Juan Basin. New Mexico (abstract): Geological Society of America. Abstracts with Program, v. 22. p. $357-358$.

Kinsmav, D.J.J., 1967, Huntite from a carbonale-evaporite environment: The American Mineralogist, $\vee .52$, p. 1332-1340.

MERCIFr. J. 1973. Etudes géolngiques des zones internes des Hellénides en Macedonie centrale. Contribution magmatique des zones internes Hellénides: Annales géologiques des Pays Helléniques, y. 20, p. 85-97.

Moustr, G., aND ForstNER, U., 1975. Recent dolomite formation in non-marine environments IX International Congress of Sedimentology. Nice. Thème 2, p. 101-108.

Mug.h:R, G., Irion, G.. Aso Forstner. U., 1972, Formation and diagenesis of inorganic Ca-Mg carbonates in the lacustrine environment: Naturwissenschaften.. . 59. p. 158-164
PrkTH:iknt J.P. 197|. Présence de magnésite et de huntite dans la Sebkha el Malah de Zarzis: Academie des Sciences (Paris). Comptes Rendus. v. 272, p. 185-188.

Perthlegot, J.P.. Castanifr, S., and Mairin, A, 1990 , La huntite $\left(\mathrm{CaMg}_{3}\left(\mathrm{CO}_{3}\right)_{4}\right)$ de la Sebkha el Melah (Zarzis, Tunisie). Un example de microbiodiagenèse carbonatogène: Societé Géologique de France. Bulletin. 8ème Série. v. 6, p. 657-666.

ReNalt. R.. 1993. Morphology, distribution, and preservation potential of microbial mats in the hydromagnesite-magnesile playas of the Cariboo Plateau. British Columbia, Canada: Hydrobiologia, v. 267, p. $75-98$

Ryder, R.T., Folich, T.D., A.ND Ellson, J.H., 1976, Early Tertiary sedimentation in the western Uinta Basin, Utah: Geological Society of America Bulletin, v. 87. p. 496-512.

ShaYan. A. 1984. Strontium in huntites from Geelong and Deer Park. Victoria, Australia: The American Mineralogist, v. 69, p. 528-530.

Shin, E.A. 1983, Birdseyes, fenestrae shrinkage pores and loferites: a reevaluation: Journal of Sedimentary Petrology, v. 53, p. 619-629.

Skiniser, B.J., 1958, Huntite from Tea Tree Gully, South Australia: The American Mineralogist. v. 43, p. $159-162$.

Stamatakis, M.G., Economou, M., Kolokotron, M., and Christoula, M., 1989, Petrology and geochemistry of the Neogene $\mathrm{Mg}$-rich sediments of Kozani-Eani-Servia area, Northern Greece: Académie Serbe des Sciences et Arts, Bulletin, v. 3!, p. 13-23.

ThralLKiLl, J.V., 1965, Studies in the excavation of limestone caves and the deposition of speleothems [unpublished $\mathrm{Ph} \mathrm{D}$. thesis]: Princeton University, $193 \mathrm{p}$.

VAN DE WEFRD, A., 1983, Palynology of some Upper Miocene and Pliocene formations in Greece: Geologisches Jahrbuch, v. 48,63 p.

VeltTzelos, E., AND KNobloch, E., 1986, Die Obermiozäne flora von Prossilion bei Kozani (Süd Mazedonien, Griechenland): Documenta Naturae, v. 29, p. 29-33.

Vitaliano, C., and BeCK. C.W., 1963, Huntite, Gabbs. Nevada: The American Mineralogist, v. 48, p. $1158-1163$

W ARREN, J.K. 1989, Evaporite Sedimentology: Importance in Hydrocarbon Accumulation: Englewood Cliffs, New Jersey, Prentice-Hall, 285 p.

W:DZENSTEIN. W., 1975, Limnische huntit-hydromagnesit-magnesit Lagerstätten in Mazedonien. Nord Griechenland: Mineralium Deposita, v. 10, p. 27-32.

WoLBERG, D.L., BeLLS, D.M., AND AustN, G.S., 1989. Paleoenvironmental implications of first documented occurrence of unusual carbonate mineral, huntite, in Late Cretaceous Fruitland Formation, San Juan Basin, New Mexico (absiract): American Association of Petroleum Geolngists, Rocky Mountain Section Meeting, Alburquerque, Abstracts, p. 1179.

ZaCHMA.NN, D.W., 1989, Mg-carbonate deposits in freshwater environment, in Möller. P., ed.. Magnesite. Geology, Mineralogy, Geochemistry, Formation of Mg-Carbonates: Monograph Series on Mineral Deposits, 28. Berlin. Gebrider Bornträger, p. 61-94.

Received 14 July 1994; accepled 17 January 1995 